www.jmscr.igmpublication.org

Impact Factor 5.244

Index Copernicus Value: 83.27

ISSN (e)-2347-176x ISSN (p) 2455-0450

crossref DOI: http://dx.doi.org/10.18535/jmscr/v4i8.15

Journal Of Medical Science And Clinical Research

\title{
Diabetic Retinopathy and Major Risk Factors Among Type 2 Diabetic Patients Attending Assiut University Hospitals
}

\author{
Authors \\ Hassan L. Fahmy ${ }^{1}$, Walaa A. Khalifa ${ }^{2}$, Mohamed Sharaf ${ }^{1}$, Asmaa M.A. Soliman ${ }^{3}$, \\ Sabra M. Ahmed ${ }^{3}$, Khaled Abdelazeem ${ }^{1}$ \\ ${ }^{1}$ Department of Ophthalmology, Faculty of Medicine, Assiut University, Egypt \\ ${ }^{2}$ Department of Internal Medicine, Faculty of Medicine, Assiut University, Egypt \\ ${ }^{3}$ Deparment of Public Health and Community Medicine, Faculty of Medicine, Assiut University, Egypt \\ Corresponding Author \\ Walaa A Khalifa \\ Assiut University, P.O. Box 71111 Assiut, Egypt \\ Telephone: +20-1111677728, Fax: +20-2333327 \\ Email:dr.walaaanwar@yahoo.com
}

\begin{abstract}
Objective: To determine the percentage of diabetic retinopathy and its associated risk factors among type 2 diabetic patients attending diabetes care clinic at Assiut university hospitals.

Method: A cross sectional study was conducted between January to December 2014, including 204 type 2 diabetic patients attending diabetes care clinic at Assiut university hospitals to be screened for diabetic retinopathy and its associated risk factors.

Results: Diabetic retinopathy(DR)was found in $24 \%$ of patients $(16.7 \%$, mild NPDR, $2.9 \%$ moderate NPDR , $3.4 \%$ diabetic macular edema and $1 \%$ PDR ). Compared to those without retinopathy, longer duration of diabetes $(11.3 \pm 7.6$ versus $5.9 \pm 5.9$ years; $P<0.001)$, higher systolic blood pressure $(121.8 \pm 6.3$ versus $121.2 \pm 5.9 ; P=0.003$ ), poor glycemic control (Hemoglobin AlC $=10.9 \pm 1.7$ versus $9.6 \pm 1.8$; $P<0.001)$ and insulin therapy $(P<0.001)$ were considered as a major risk factors for DR. Other risk factors include lower HDL (41.8 \pm 28.3 versus $53.4 \pm 36.4 ; P<0.001)$, higher level of total cholesterol, serum creatinine. Insulin therapy and high total cholesterol level were the most significant independent risk factors. Conclusion: Early screening, tight glycemic control, control of hypertension and dyslipidemia play an important role in the prevention of sight-threatening retinopathy. Also insulin treatment should be taken into consideration when managing a case of DR.
\end{abstract}

Keywords: Diabetic retinopathy, Diabetic macular edema, screening, Risk factors, insulin treatment

\section{INTRODUCTION}

Diabetic retinopathy (DR) is the leading cause of vision loss in adults aged 20-74 years ${ }^{[1]}$. From 19902010, DR ranked as the fifth most common cause of preventable blindness and fifth most common cause of moderate to severe visual impairment ${ }^{[2]}$

Proliferative diabetic retinopathy (PDR) is the most common vision-threatening lesion particularly among patients with type 1 diabetes. However, diabetic macular edema (DME) is responsible for most of the visual 
loss experienced by patients with diabetes as it remains the major cause of vision loss in the highly prevalent type 2 diabetes ${ }^{[3]}$ and is invariably present in patients with type 2 diabetes with PDR $^{[4]}$. In addition to vision loss, DR and DME have also been shown to contribute to the development of other diabetes-related complications including nephropathy, peripheral neuropathy and cardiovascular events ${ }^{[5]}$.

Early detection, control and treatment of diabetes itself will help in reduction in cases of diabetic retinopathy and to delay progression of non-proliferative diabetic retinopathy (NPDR) to PDR. The factors, which have a contribution in presence and progression of visual impairment, due to DR are modifiable (blood glucose, blood pressure, serum lipids, obesity, alcohol, and smoking), non-modifiable (duration, age, sex) ${ }^{[6]}$ and other independent variables like type of diabetes mellitus, family history of DR. More focus should be towards modifiable risk factors. Long term protection is possible if blood glucose levels are controlled which reduces microvascular complications and progression of severity of $\mathrm{DR}^{[7]}$. Similarly, better blood pressure control in diabetic patients reduces progression of DR. Antihypertensive medication with renin-angiotensin system blockade helps in prevention of occurrence of DR in type 1 and of its progression in type $2 \mathrm{DM}^{[7]}$. Lowering of blood lipids is beneficial to diabetic maculopathy because it results in less retinal vessel leakage and hard exudate formation.

National data regarding the percentage of diabetic retinopathy among type 2 diabetic patients, the severity of visual impairment occurred and major risk factors predisposing to its development in the Egyptian population are lacking. Therefore, this study was conducted.

\section{PATIENTS AND METHODS}

Sampling: Sample size was calculated considering the expected frequency of $40 \%$ as reported among Kuwaiti diabetic patients ${ }^{(8)}$ and the worst acceptable level of 50\%, the required sample size was 92 by using EPI INFO version 3.5.1 (2008). Considering design effect of 2. The required sample size was 184.

Study design: A cross-sectional study was carried out.

Study population: diabetic patients attending diabetes care clinic in Assiut university hospitals selected by simple random sampling method, between January to December 2014

Target population: type 2 diabetic patients with diabetic retinopathy.

Inclusion Criteria: Type 2diabetes attending outpatient clinic.

Exclusion Criteria:

1. Type 1 diabetic patients

2. Presence of ocular diseases that could interfere with fundus examination ,eg ,bilateral corneal opacities or dense cataract

3. Associated diseases that can affect retina like Systemic vasculities and connective tissue diseases

\section{Instruments and methods of Data Collection}

Data were collected using structured interview questionnaires. The demographic information of each study subject including his/her name, age, sex, address was taken after obtaining informed consent.

History containing study variables like duration of diabetes, current therapy intake either insulin or oral hypoglycemic medications, smoking status, and family history of diabetes was recorded.

Complete clinical examination .Body mass index (BMI) was calculated as weight in kilogram divided by height in meter square [weight $(\mathrm{Kg}) /$ Height $\left(\mathrm{m}^{2}\right)$ ]. Blood pressure of each subject was measured in right arm, supine position. Two readings were taken 30 minutes apart and the average of two was taken as a final reading. In our study the patients were considered hypertensive if their blood pressure >140/90 or who reported being on treatment for hypertension. 
The diagnosis of artery heart disease (CAD) was established if the patient had ECG proven coronary ischemia or history of acute coronary syndrome and or stable angina, coronary angioplasty or coronary artery by-pass grafting.

Clinical neurological examination performed to assess the presence of peripheral polyneuropathy including pressure sensation detected by using $10 \mathrm{~g}$ monofilament.

Ophthalmic examination: Visual acuity was measured using Snellen's chart. A slit lamp was used for anterior segment evaluation. IOP measurement was performed by Goldman a planation tonometer. Indirect ophthalmoscopy was done after complete pupillary dilatation by $1 \%$ tropicamide eye drops. Classification of retinopathy was based on fundus examination findings of the worst eye of each subject.

Laboratory investigations: Complete blood picture. Glycemic control was measured by Hemoglobin A1C (HbA1C). Complete lipid profile estimating of total serum cholesterol, high density lipoprotein, and serum triglycerides (TG). Renal function assessment by measurement of blood urea and serum creatinine levels was performed.

\section{RESULT}

The study included 204 patients, $64.7 \%$ were females, mean age was $49.4 \pm 12.8$ years with mean duration of diabetes $7.1 \pm 6.3$ years. $39.7 \%$ were being treated by insulin only. $8.3 \%$ were current smoker. $48 \%$ had hypertension. Mean systolic \& diastolic blood pressure were $121 \pm 6.0$ and $81.8 \pm 9.6$ respectively. Mean body mass index was $30.1 \pm 4.4$. HbA1c was $\geq 7 \%$ in95.5\% . Mean Total cholesterol \& Triglyceride level was $204.9 \pm 42.4 \& 195.2 \pm 118.6$ respectively. Peripheral neuropathy was found in $62.3 \%$ of patients. Diabetic retinopathy was found in $24 \%$ (mild NPDR was present in $16.7 \%$, moderate NPDR in $2.9 \%$, macular edema in $3.4 \%$ and PDR in $1 \%$ of patients).

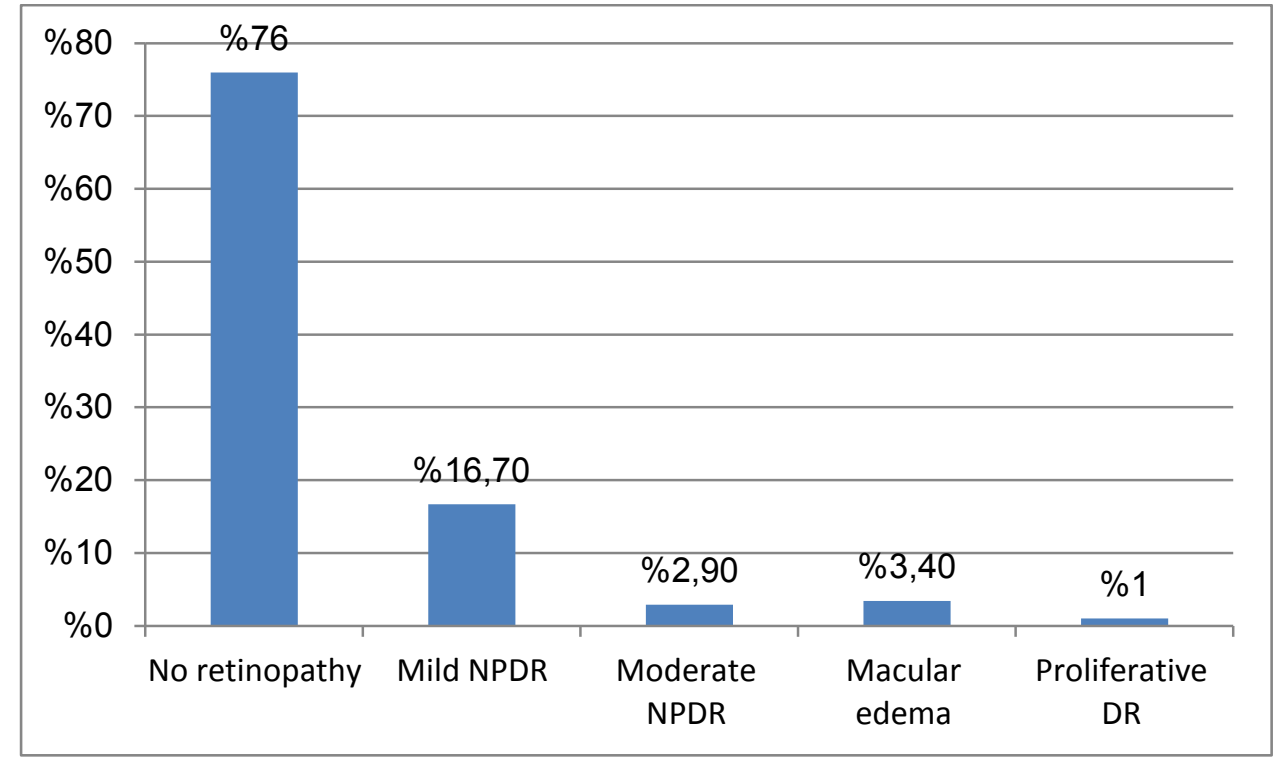

Figure (1) : Percentage of DR and its different types 
Table (1): baseline Characteristics of included patients

\begin{tabular}{|c|c|}
\hline Characteristics & No. $(\%)$ \\
\hline $\begin{array}{l}\text { Gender: } \\
-\quad \text { Male } \\
-\quad \text { Female }\end{array}$ & $\begin{array}{l}72(35.3) \\
132(64.7)\end{array}$ \\
\hline $\begin{array}{l}\text { Age (years): } \\
-\quad<40 \\
-\quad 40-<50 \\
-\quad 50-<60 \\
-\quad \geq 60\end{array}$ & $\begin{array}{l}47(23.0) \\
65(31.9) \\
59(28.9) \\
33(16.2)\end{array}$ \\
\hline $\begin{array}{l}\text { Duration (years): } \\
-\quad \leq 5 \\
-\quad 5-10 \\
-\quad \geq 10\end{array}$ & $\begin{array}{l}93(45.4) \\
67(32.7) \\
44(21.4)\end{array}$ \\
\hline $\begin{array}{ll}\text { Diabetes treatment: } \\
\text { - } & \text { Oral hypoglycemic } \\
- & \text { Insulin } \\
- & \text { Combined }\end{array}$ & $\begin{array}{c}120(58.8) \\
81(39.7) \\
3(1.5)\end{array}$ \\
\hline Smoker & $6(8.3)$ \\
\hline Hypertension & $98(48.0)$ \\
\hline $\begin{array}{l}\text { Systolic blood pressure } \\
\text { Diastolic blood pressure }\end{array}$ & $\begin{array}{l}121 \pm 6.0 \\
81.8 \pm 9.6\end{array}$ \\
\hline Body mass index & $30.1 \pm 4.4$ \\
\hline $\begin{array}{l}\text { HA1C: } \\
-\quad<7 \\
-\quad 7-8 \\
-\quad>8 \\
\text { Mean } \pm \text { SD }\end{array}$ & $\begin{array}{c}9(4.5) \\
27(13.4) \\
168(82.1) \\
9.9 \pm 1.8\end{array}$ \\
\hline Total cholesterol (mg/dl) & $204.9 \pm 42.4$ \\
\hline Triglyceride (mg/dl) & $195.2 \pm 118.6$ \\
\hline Coronary artery diseases (CAD) & $23(11.3)$ \\
\hline Dislipidemia: & $24(11.8)$ \\
\hline Peripheral neuropathy: & $127(62.3)$ \\
\hline $\begin{array}{l}\text { Lens: } \\
\text { - } \quad \text { Clear } \\
-\quad \text { Cataract }\end{array}$ & $\begin{array}{l}134(65.7) \\
70(34.5)\end{array}$ \\
\hline $\begin{array}{ll}\text { Fundus examination: } \\
\text { - } & \text { No diabetic retinopathy } \\
\text { - } & \text { Mild NPDR } \\
\text { - } & \text { Moderate NPDR } \\
\text { - } & \text { Sever NPDR } \\
\text { - } & \text { Macular edema } \\
\text { - } & \text { Proliferative DR }\end{array}$ & $\begin{array}{c}155(76.0) \\
34(16.7) \\
6(2.9) \\
0(0) \\
7(3.4) \\
2(1.0)\end{array}$ \\
\hline
\end{tabular}

Patients with any type of DR has significantly longer duration of diabetes $(11.3 \pm 7.6$ versus $5.9 \pm 5.9$ years; $\mathrm{P}<0.001)$. The risk of DR has increased from $12.9 \%$ in patients who had diabetes < 5 years to $47.7 \%$ in patients who had diabetes $>10$ years $(\mathrm{P}<0.001)$. The percentage of patients with DR was higher among those treated with insulin $(\mathrm{p}<0.001)$ and inhypertensive compared to normotensive patients $(33.7 \%$ versus $15.1 \%, \mathrm{P}<0.05)$. Other risk factors of $\mathrm{DR}$ were poor glycemic control $(\mathrm{p}<0.001)$, dyslipidemia $(41.7 \%$ versus $21.7 \%)(\mathrm{P}<0.05)$ andhigher Serum Creatinine level $(115.6 \pm 76.8$ versus $91.2 \pm 44.6 \mathrm{mg} / \mathrm{dl} ; \mathrm{P}<0.05)$ 
Table (2): Univariate analysis of clinical characteristics of diabetic patients with and without retinopathy

\begin{tabular}{|c|c|c|c|}
\hline Characteristics & $\begin{array}{l}\text { No retinopathy } \\
\text { No. }(\mathrm{C} \%)(\mathrm{R} \%)\end{array}$ & $\begin{array}{l}\text { Any type of DR } \\
\text { No. }(\mathbf{C} \%)(\mathbf{R} \%)\end{array}$ & P-value \\
\hline $\begin{array}{l}\text { Gender: } \\
-\quad \text { Male } \\
-\quad \text { Female }\end{array}$ & $\begin{array}{c}51(33.5)(71.8) \\
103(66.5)(78.0)\end{array}$ & $\begin{array}{l}20(40.8)(28.2) \\
29(59.2)(22.0)\end{array}$ & 0.335 \\
\hline $\begin{array}{c}\text { Age (years): } \\
-\quad \leq 40 \\
-\quad \mathbf{4 0}- \\
-\quad 50- \\
-\quad \geq 60\end{array}$ & $\begin{array}{l}38(24.5)(80.9) \\
46(29.7)(70.8) \\
44(28.4)(74.6) \\
27(17.4)(81.8)\end{array}$ & $\begin{array}{l}9(18.4)(19.1) \\
19(38.8)(29.2) \\
15(30.6)(25.4) \\
6(12.2)(18.2)\end{array}$ & 0.521 \\
\hline Mean \pm SD & $49.1 \pm 13.1$ & $50.3 \pm 11.8$ & 0.544 \\
\hline $\begin{array}{l}\text { Diabetes duration (years): } \\
-\quad<5 \\
-\quad 5-10 \\
-\quad>10\end{array}$ & $\begin{array}{l}81(52.3)(87.1) \\
51(32.9)(76.1) \\
23(14.8)(52.3)\end{array}$ & $\begin{array}{l}12(24.5)(12.9) \\
16(32.7)(23.9) \\
21(42.9)(47.7)\end{array}$ & $<0.001$ \\
\hline Mean \pm SD & $5.9 \pm 5.9$ & $11.3 \pm 7.6$ & $<0.001$ \\
\hline $\begin{array}{l}\text { Diabetes treatment: } \\
-\quad \text { Oral hypoglycemic } \\
-\quad \text { Insulin }\end{array}$ & $\begin{array}{c}104(67.1)(86.7) \\
51(32.9)(60.7)\end{array}$ & $\begin{array}{l}16(32.7)(13.3) \\
33(67.3)(39.3)\end{array}$ & $<0.001$ \\
\hline $\begin{array}{l}\text { Hypertension: } \\
-\quad \text { Yes } \\
-\quad \text { No } \\
\end{array}$ & $\begin{array}{l}65(41.9)(66.3) \\
90(58.1)(84.9)\end{array}$ & $\begin{array}{l}33(67.3)(33.7) \\
16(32.7)(15.1)\end{array}$ & $<0.05$ \\
\hline Systolic blood pressure & $121.2 \pm 5.9$ & $121.8 \pm 6.3$ & $<0.05$ \\
\hline Diastolic blood pressure & $80.7 \pm 9.0$ & $85.3 \pm 10.3$ & 0.579 \\
\hline Body mass index & $30.04 \pm 4.5$ & $30.1 \pm 4.2$ & 0.891 \\
\hline $\begin{array}{l}\text { CAD: } \\
-\quad \text { Yes } \\
-\quad \text { No }\end{array}$ & $\begin{array}{c}15(9.7)(65.2) \\
140(0.3)(77.3)\end{array}$ & $\begin{array}{c}8(16.3)(34.8) \\
41(83.7)(22.7)\end{array}$ & 0.200 \\
\hline $\begin{array}{l}\text { Peripheral neuropathy: } \\
-\quad \text { Yes } \\
-\quad \text { No }\end{array}$ & $\begin{array}{l}91(58.7)(71.6) \\
64(41.3)(83.1)\end{array}$ & $\begin{array}{l}36(73.5)(28.4) \\
13(26.5)(16.9)\end{array}$ & 0.063 \\
\hline $\begin{array}{l}\text { Lens: } \\
-\quad \text { Clear } \\
-\quad \text { Cataract }\end{array}$ & $\begin{array}{c}109(70.3)(81.3) \\
46(29.7)(65.7)\end{array}$ & $\begin{array}{l}25(51.0)(18.7) \\
24(49.0)(34.3)\end{array}$ & 0.013 \\
\hline $\begin{array}{l}\text { Dislipidemia: } \\
-\quad \text { Yes } \\
-\quad \text { No } \\
\end{array}$ & $\begin{array}{c}14(9.0)(58.3) \\
141(91.0)(78.3)\end{array}$ & $\begin{array}{c}10(20.4)(41.7) \\
39(79.6)(21.7)\end{array}$ & $<0.05$ \\
\hline
\end{tabular}


Table (3): Univariate laboratory characteristics of diabetic patients with and without retinopathy:

\begin{tabular}{|c|c|c|c|}
\hline Characteristics & $\begin{array}{l}\text { No retinopathy } \\
\text { No. }(\mathrm{C} \%)(\mathrm{R} \%)\end{array}$ & $\begin{array}{l}\text { Any type of DR } \\
\text { No. (C\%) (R\%) }\end{array}$ & P-value \\
\hline $\begin{array}{l}\text { HbA1C: } \\
-\quad<7-8 \% \\
-\quad>8 \% \\
\text { Mean } \pm \text { SD }\end{array}$ & $\begin{array}{c}33(21.9)(91.7) \\
118(78.1)(72.4) \\
9.6 \pm 1.8\end{array}$ & $\begin{array}{c}3(6.2)(8.3) \\
45(93.8)(27.6) \\
10.9 \pm 1.7\end{array}$ & $<0.001$ \\
\hline $\begin{array}{l}\text { Blood urea: } \\
-\quad \text { Normal }(15-45 \mathrm{mg} / \mathrm{dl}) \\
-\quad \text { High }(>45 \mathrm{mg} / \mathrm{dl}) \\
\text { Mean } \pm \text { SD }\end{array}$ & $\begin{array}{c}141(96.6)(75.8) \\
5(3.4)(71.4) \\
13.8 \pm 23.4\end{array}$ & $\begin{array}{c}45(95.7)(24.2) \\
2(4.3)(28.6) \\
18.0 \pm 19.1\end{array}$ & $\begin{array}{l}0.791 \\
0.269\end{array}$ \\
\hline $\begin{array}{l}\text { Serum Creatinine: } \\
-\quad \text { Normal }(0.8-1.2 \mathrm{mg} / \mathrm{dl}) \\
-\quad \text { High }(>1.2 \mathrm{mg} / \mathrm{dl}) \\
\text { Mean } \pm \mathrm{SD}\end{array}$ & $\begin{array}{l}13(8.9)(68.4) \\
133(91.1)(76.9) \\
91.2 \pm 44.6\end{array}$ & $\begin{array}{l}6(13.0)(31.6) \\
40(87.0)(23.1) \\
115.6 \pm 76.8\end{array}$ & $\begin{array}{l}0.412 \\
<0.05\end{array}$ \\
\hline $\begin{array}{l}\text { HDL: } \\
-\quad \text { Low risk }(>35 \mathrm{mg} / \mathrm{dl}) \\
-\quad \text { High risk }(<35 \mathrm{mg} / \mathrm{dl}) \\
\text { Mean } \pm \mathrm{SD}\end{array}$ & $\begin{array}{c}138(92.0)(85.2) \\
12(8.0)(33.3) \\
53.4 \pm 36.4\end{array}$ & $\begin{array}{c}24(50.0)(14.8) \\
24(50.0)(67.4) \\
41.8 \pm 28.3\end{array}$ & $\begin{array}{l}<0.001 \\
0.041\end{array}$ \\
\hline $\begin{array}{l}\text { LDL: } \\
-\quad \text { Low risk }(\leq 130 \mathrm{mg} / \mathrm{dl}) \\
-\quad \text { High risk }(>130 \mathrm{mg} / \mathrm{dl}) \\
\text { Mean } \pm \mathrm{SD}\end{array}$ & $\begin{array}{c}106(89.8)(84.1) \\
12(10.2)(38.7) \\
106.1 \pm 86.7\end{array}$ & $\begin{array}{c}20(51.3)(15.9) \\
19(48.7)(61.3) \\
120.7 \pm 33.0\end{array}$ & $\begin{array}{l}<0.001 \\
0.305\end{array}$ \\
\hline $\begin{array}{l}\text { Total cholesterol: } \\
-\quad \text { Low risk }(\leq 180 \mathrm{mg} / \mathrm{dl}) \\
-\quad \text { High risk }(>180 \mathrm{mg} / \mathrm{dl}) \\
\text { Mean } \pm \mathrm{SD}\end{array}$ & $\begin{array}{c}33(21.9)(94.3) \\
118(78.1)(72.0) \\
190.9 \pm 32.4\end{array}$ & $\begin{array}{c}2(4.2)(5.7) \\
46(95.8)(28.0) \\
248.9 \pm 40.3\end{array}$ & $\begin{array}{l}0.005 \\
<0.001\end{array}$ \\
\hline $\begin{array}{l}\text { Triglycerides: } \\
-\quad \text { Low risk }(\leq 150 \mathrm{mg} / \mathrm{dl}) \\
-\quad \text { High risk }(>150 \mathrm{mg} / \mathrm{dl}) \\
\text { Mean } \pm \mathrm{SD}\end{array}$ & $\begin{array}{c}86(57.0)(95.6) \\
65(43.0)(59.6) \\
163.0 \pm 99.2\end{array}$ & $\begin{array}{c}4(8.3)(4.6) \\
44(91.7)(40.1) \\
296.6 \pm 118.6\end{array}$ & $<0.001$ \\
\hline $\begin{array}{l}\text { HB level: } \\
-\quad<12 \mathrm{gm} / \mathrm{dl} \\
-\quad \geq 12 \mathrm{gm} / \mathrm{dl} \\
\text { Mean } \pm \text { SD }\end{array}$ & $\begin{array}{c}73(49.0)(73.7) \\
76(51.0)(78.4) \\
11.9 \pm 1.0 \\
\end{array}$ & $\begin{array}{c}26(55.3)(26.3) \\
21(44.7)(21.6) \\
11.9 \pm 1.1\end{array}$ & 0.964 \\
\hline
\end{tabular}

Multiple logistic regression analysis was performed to determine independent effects of associated risk factors on diabetic retinopathy. The results showed that the only significant independent factors associated with diabetic retinopathy are insulin as a type of treatment of diabetes and high total cholesterol level.

\section{DISCUSSION}

The overall prevalence of DR observed in our study was (24\%) and only (2.9\%) has DME, which is concordant with the global documented data 2012 regarding the prevalence of DR in Egypt which was $20.5 \%{ }^{(9,10)}$ Taking into consideration that patients attending our center in Assiut University tend to be an 
older population with a long duration of diabetes, poor diabetic control and lower socioeconomic status and this was a major motivation for us to undertake this work. When compared our results to that reported in middle east and north Africa region, we showed a lower prevalence of DR than those reported in Yemen $55 \%$, Kuwait $40 \%$, Saudi Arabia $34.6 \%$ and Jordan $64.1 \%{ }^{(8,9,10)}$, and it is higher than that reported in Morocco $10 \%$, Tunisia $18.3 \%$ and Bahrain $10 \% .{ }^{(9,10)}$ This difference of prevalence could be explained by the fact that most of these studies were population based compared to our study which had smaller sample size and exclusion of type $1 \mathrm{DM}$. Also different tools were used for measurement.

Regarding the grades of retinopathy, we found that the proportion of mild grade of retinopathy was higher than that reported from Kuwait, Saudi Arabia and a lower proportion of DME $2.9 \%$ sight threatening retinopathy than Kenya $33.3 \%$ and Kuwait $20.6 \%^{(11,8)}$

Our study found no significant gender difference in the development of DR, which is in accordance with multiple studies mostly from USA and Middle East ${ }^{(12)}$ but in contrast other studies from India, and UAE observed to be more prevalent in male diabetics. ${ }^{(13,14)}$

Also a significant association between DR and duration of diabetes was observed which is consistent with most of the previous studies ${ }^{(10,12)}$, while the age of the patient had no significant association.

Hypertension especially systolic hypertension was considered as a risk factor for DR in this study, also the vascular damage caused by hypertension has an additive effect on the severity of DR. different previous studies from Jordan and Kuwait ${ }^{(8)}$ revealed that DR is significantly associated with hypertension. While in contrast, a study in India ${ }^{(13)}$ found no significant role of hypertension in the development of DR.

It is well known that hyperglycemia is one of the most important determinants of diabetic microvascular complications $^{(15)}$, this was also observed in our study as patients with DR had higher mean HbA1c $10.9 \pm$ 1.7 versus $9.6 \pm 1.8$ in patients without DR.

A recent meta-analysis of case-control studies revealed that mean levels of serum TC, LDL-C, and TG were significantly higher in patients with DR and DME compared with those without DME and this is consistent with our results, as total cholesterol (TC) and serum low-density lipoprotein cholesterol (LDL-C) are associated with the presence of hard exudates in patients with $\mathrm{DR}^{(16)}$

The effect obesity on DR has been relatively well-studied but with inconclusive and conflicting findings, a recent study reported that persons with higher body mass index and larger neck circumference were found more likely to have DR and more severe $\mathrm{DR}^{(17)}$, while BMI did not appear as significant risk factors as reported by the studies in $\mathrm{UAE}^{[14]}$ which is consistent with our results.

It was evident that Increasing severity of DR was associated with increasing severity of chronic kidney disease and decreased estimated glomerular filtration rate ${ }^{(18)}$,and we showed that diabetic patients with diabetic retinopathy had significantly higher Serum Creatinine level(115.6 \pm 76.8 versus $91.2 \pm 44.6 \mathrm{mg} / \mathrm{dl}$; $\mathrm{P}<0.05$ ). Hence assessment of the renal parameters-blood urea, serum creatinine and microalbumuria, is important, especially if DR is present.

DR in Type 2 diabetes is found to be associated with a 1.7-fold increased risk of cardiovascular events, such as stroke, coronary artery disease (CAD), and heart failure ${ }^{(19)}$, but in our study no significant association was observed between DR and CAD

As regarding insulin treatment, we observed higher prevalence of DR among patients on insulin therapy compared to those on oral therapy, also insulin was found to be an independent risk factor for the development of DR, and this was also proved in two recent studies in Saudi Arabia ${ }^{(20)}$.

\section{LIMITATIONS}

- Small sample size

- Lack of intensive technologies for screening which are costy. 


\section{RECOMMENDATIONS}

- A population based study is recommended to identify the risk factors as well as the prevalence of diabetic retinopathy.

- The community should be regularly educated on DR

- Physicians and family doctors should focus on the control of the risk factors of DR.

\section{ACKNOWLEDGEMENTS}

The authors wish to acknowledge the staff and workers in diabetes care clinic at Assiut University Hospitals for their support to this study.

\section{CONFLICT OF INTERESTS}

The authors declare that there was no conflict of interests as regard the publication of this paper.

\section{REFERENCES}

1. Cheung N, Mitchell P, Wong TY. Diabetic retinopathy.Lancet. 2010;376(9735):124-36.

2. Bourne RR, Stevens GA, White RA, Smith JL, Flaxman SR, Price H, et al. Causes of vision loss worldwide, 1990-2010: a systematic analysis. Lancet Glob Health. 2013;1(6):e339-49.

3. Lightman S, Towler HM. Diabetic retinopathy. Clin Cornerstone. 2003;5(2):12-21.

4. Tong L, Vernon SA, Kiel W, Sung V, Orr GM. Association of macular involvement with proliferative retinopathy in type 2 diabetes. DiabetMed. 2001;18(5):388-94.

5. He F, Xia X, Wu XF, Yu XQ, Huang FX. Diabetic retinopathy in predicting diabetic nephropathy in patients with type 2 diabetes and renal disease: a meta-analysis. Diabetologia. 2013;56(3):457-66.

6. Peter H. Scanlon, Stephen J. Aldington, Irene Strattion. epidemiological issues in diabetic retinopathy, diabetic retinopathy update. Middle East African Journal of Ophthalmology. 2013;20(4):293-300.

7. Ghanchi F, et al. The royal college of ophthalmologists' clinical guidelines for diabetic retinopathy: a summary. Eye. 2013;27(2):285-87.

8. Ataf MS Al-Adsani: risk factors of for diabetic retinopathy in Kuwaiti type 2 diabetic patients, Saud. Med. J. 2007, 28(4): 579 - 83)

9. Rajiv Khandekar.Screening and public health strategies for diabetic retinopathy in the Eastern Mediterranean region. Middle East Afr J Ophthalmol. 2012;19:178-184.

10. Yau JW, Rogers SL, Kawasaki R, Lamoureux EL, Kowalski JW, Bek T, et al. Global prevalence and major risk factors of diabetic retinopathy. Diabetes Care. 2012;35:556-64

11. Mathenge W, Bastawrous A, Peto T, Leung I, Yorston D, Foster A, et al. Prevalence and correlates of diabetic retinopathy in a population-based survey of older people in Nakuru, Kenya. Ophthalmic Epidemiol. 2014;21(3):169-77.

12. Zhang X, Saaddine JB, Chou CF, Cotch MF, Cheng YJ, Geiss LS, et al. Prevalence of diabetic retinopathy in the United States, 2005-2008. JAMA. 2010;304:649-56

13. Raman R, Rani PK, ReddiRachepalle S, Gnanamoorthy P, Uthra S, Kumaramanickavel G, et al. Prevalence of diabetic retinopathy in India: SankaraNethralaya diabetic retinopathy epidemiology and molecular genetics study report 2. Ophthalmology. 2009;116:311-8.

14. Al-Maskari F, El-Sadig M. Prevalence of diabetic retinopathy in the United Arab Emirates: A crosssectional survey. BMC Ophthalmol. 2007;7:11.

15. Rodriguez-Fontal M, Kerrison JB, Alfaro DV, Jablon EP. Metabolic control and diabetic retinopathy. Curr Diabetes Rev 2009;5:3-7. 


\section{JMSCR Vol||04||Issue||08||Page 11782-11790||August}

16. Das R, Kerr R, Chakravarthy U, Hogg RE. Dyslipidemia and diabetic macular edema: A systematic review and meta-analysis. Ophthalmology 2015;122:1820-7.

17. Dirani M, Xie J, Fenwick E, Benarous R, Rees G, Wong TY, et al. Are obesity and anthropometry risk factors for diabetic retinopathy? The diabetes management project. Invest Ophthalmol Vis Sci 2011;52:4416-21.

18. Grunwald JE, Alexander J, Ying GS, Maguire M, Daniel E, Whittock-Martin R, et al. Retinopathy and chronic kidney disease in the Chronic Renal Insufficiency Cohort (CRIC) study. Arch Ophthalmol. 2012;130(9):1136-44.

19. Rosenson RS, Fioretto P, Dodson PM. Does microvascular disease predict macrovascular events in type 2 diabetes? Atherosclerosis 2011;218:13-8.

20. Razia A. Ahmed, Shamsun N. Khalil, and Mohammad A. A. Al-Qahtani. Diabetic retinopathy and the associated risk factors in diabetes type 2 patients in Abha, Saudi Arabia,J Family Community Med. 2016 Jan-Apr; 23(1): 18-24. 